\title{
SIDE effects associated with use of nevirapine in HIV treatment naïve patients with respect to baseline CD4 count
}

\section{Manoj Shevkani*, Bankim Mankad, Goral Rathod, Bipin Amin, Asha Shah, Umesh Nihalani, Hemang Purohit,} Burzin Kavina, Urvi Derasari, Sanjeev Prajapati

From $16^{\text {th }}$ International Symposium on HIV and Emerging Infectious Diseases

Marseille, France. 24-26 March 2010

\section{Background}

This study aims to detect Nevirapine (NVP) side effects among patients started with lead in dose at initiation of Anti Retroviral Therapy (ART) with CD4 count $>250$ cells $/ \mathrm{mm}^{3}$ in female and CD4 count $>400$ cells $/ \mathrm{mm}^{3}$ in male.

\section{Methods}

Close monitoring was conducted for the detection of NVP based side effects among ART - naïve patients initiated on CD4 count $>250$ cells $/ \mathrm{mm}^{3}$ among women and CD4 count $>400$ cells $/ \mathrm{mm}^{3}$ are the study target at Centre of Excellence (CoE), ART Centre, B. J. Medical College, Civil Hospital, Ahmedabad, Gujarat, India.

\section{Results}

Total 5060 patients were initiated ART during the period of may 2005 to may 2009 at the institute. Among this 3647 (72\%) were initiated with NVP lead in dose as per the Indian National ART Guidelines, Table 1.

Table 1

\begin{tabular}{|c|c|c|}
\hline & Parameter & Outcome \\
\hline \multicolumn{2}{|c|}{ NVP lead in dose initiated patients } & $3647(n)$ \\
\hline & Male & $2408(66.02 \%)$ \\
\hline & Female & 1239(33.97\%) \\
\hline \multicolumn{2}{|c|}{ Male with CD4 >400 cells $/ \mathrm{mm}^{3}$ and initiated NVP lead in dose $(n=2408)$} & $47(1.95 \%)$ \\
\hline \multicolumn{2}{|c|}{ Female with CD4 $>250$ cells $/ \mathrm{mm}^{3}$ and initiated NVP lead in dose $(\mathrm{n}=1239)$} & $112(9.03 \%)$ \\
\hline \multirow[t]{2}{*}{ NVP induced Rash } & Male $(n=47)$ & 0 \\
\hline & Female $(\mathrm{n}=112)$ & $5(4.46 \%)$ \\
\hline \multirow[t]{2}{*}{ NVP induced Hepatitis } & Male $(n=47)$ & $1(2.12 \%)$ \\
\hline & Female $(\mathrm{n}=112)$ & 0 \\
\hline \multicolumn{2}{|c|}{ Male with CD4 $<400$ cells $/ \mathrm{mm}^{3}$ and initiated NVP lead in dose $(n=2408)$} & $1629(67.64 \%)$ \\
\hline \multicolumn{2}{|c|}{ Female with CD4 <250 cells $/ \mathrm{mm}^{3}$ and initiated NVP lead in dose $(n=1239)$} & $838(67.63 \%)$ \\
\hline \multirow[t]{2}{*}{ NVP induced Rash } & Male $(n=1629)$ & $19(1.16 \%)$ \\
\hline & Female $(\mathrm{n}=838)$ & $15(1.78 \%)$ \\
\hline \multirow[t]{2}{*}{ NVP induced Hepatitis } & Male $(n=1629)$ & $5(0.30 \%)$ \\
\hline & Female $(n=838)$ & $2(0.23 \%)$ \\
\hline
\end{tabular}

\footnotetext{
* Correspondence: coe.art.ahmedabad@gmail.com
}

ART Center B J Medical College, Ahmedabad, India 


\section{Discussion}

Skin Rash was recovered on substituting with another NNRTI- Efavirenz (EFV) and the treatment was well tolerated. Hepatitis was managed with substitution to EFV and close follow-up on ALT and AST. Though western literature has a black box warning for use of NVP, this data shows if closely monitored it could be given at resources limited settings with CD4 counts $>250$ cells/ $\mathrm{mm}^{3}$ in females and $>400$ cells $/ \mathrm{mm}^{3}$ males. Nevirapine is cost effective molecule compared to Efavirenz and when given in such conditions of higher CD4 need close follow up.

Published: 11 May 2010

doi:10.1186/1742-4690-7-S1-014

Cite this article as: Shevkani et al:: SIDE effects associated with use of nevirapine in HIV treatment naïve patients with respect to baseline CD4 count. Retrovirology 2010 7(Suppl 1):014.

Submit your next manuscript to BioMed Central and take full advantage of:

- Convenient online submission

- Thorough peer review

- No space constraints or color figure charges

- Immediate publication on acceptance

- Inclusion in PubMed, CAS, Scopus and Google Scholar

- Research which is freely available for redistribution

Submit your manuscript at www.biomedcentral.com/submit 